\title{
Electrical characterization of the root system: a noninvasive approach to study plant stress responses
}

\author{
Imre Cseresnyés ${ }^{1} \cdot$ Tünde Takács $^{1} \cdot$ Bettina Sepovicss ${ }^{1}$ Ramóna Kovács ${ }^{1} \cdot$ Anna Füzy $^{1}$. István Parádi ${ }^{1,2}$. \\ Kálmán Rajkai ${ }^{1}$
}

Received: 8 November 2018 / Revised: 11 August 2019 / Accepted: 22 August 2019 / Published online: 5 September 2019

(c) The Author(s) 2019

\begin{abstract}
A pot experiment was designed to demonstrate that the parallel, single-frequency detection of electrical capacitance $\left(C_{\mathrm{R}}\right)$, impedance phase angle $\left(\Phi_{\mathrm{R}}\right)$, and electrical conductance $\left(G_{\mathrm{R}}\right)$ in root-substrate systems was an adequate method for monitoring root growth and some aspects of stress response in situ. The wheat cultivars 'Hombar' and 'TC33' were grown in a rhyolite-vermiculite mixture under control, and low, medium, and high alkaline $\left(\mathrm{Na}_{2} \mathrm{CO}_{3}\right)$ conditions with regular measurement of electrical parameters. The photochemical efficiency $\left(F_{\mathrm{v}} / F_{\mathrm{m}}\right)$ and SPAD chlorophyll content were recorded nonintrusively; the green leaf area (GLA), shoot dry mass (SDM), root dry mass (RDM), and root membrane stability index (MSI) were determined after harvest. $C_{R}$ progressively decreased with increasing alkalinity due to impeded root growth. Strong linear $C_{\mathrm{R}}-\mathrm{RDM}$ relationships $\left(R^{2}=0.883-0.940\right)$ were obtained for the cultivars. Stress reduced $\left|\Phi_{\mathrm{R}}\right|$, presumably due to the altered membrane properties and anatomy of the roots, including primarily enhanced lignification. $G_{R}$ was not reduced by alkalinity, implying the increasing symplastic conductivity caused by the higher electrolyte leakage indicated by decreasing root MSI. $F_{\mathrm{v}} / F_{\mathrm{m}}$, SPAD value, GLA, and SDM showed decreasing trends with increasing alkalinity. Cultivar 'TC33' was comparatively sensitive to high alkalinity, as shown by the greater relative decrease in $C_{\mathrm{R}}$, SDM, and RDM under stress, and by the significantly lower MSI and higher (moderately reduced) $\left|\Phi_{R}\right|$ compared to the values obtained for 'Hombar'. Electrical root characterization proved to be an efficient non-intrusive technique for studying root growth and stress responses, and for assessing plant stress tolerance in pot experiments.
\end{abstract}

Keywords Alkaline stress $\cdot$ Electrical capacitance $\cdot$ Electrical conductance $\cdot$ Membrane stability index $\cdot$ Phase angle $\cdot$ Root growth

\section{Introduction}

Several technical difficulties limit or restrict the access to root growth and functional parameters in natural soil environments (Milchunas 2012). Therefore, non-intrusive methods, including those based on electrical characterization of

Communicated by M. Horbowicz.

Imre Cseresnyés

cseresnyes.imre@agrar.mta.hu

1 Institute for Soil Sciences and Agricultural Chemistry, Centre for Agricultural Research, Hungarian Academy of Sciences, Herman Ottó út 15, Budapest 1022, Hungary

2 Department of Plant Physiology and Molecular Plant Biology, Eötvös Loránd University, Pázmány Péter Stny. 1/A, Budapest 1117, Hungary the root system in situ, have received increasing attention in recent years (Khaled et al. 2018). Significant correlations between the electrical capacitance of the root-substrate system $\left(C_{\mathrm{R}}\right.$; Table 1$)$ and the root system size were first found by Chloupek (1972) in various crops. $C_{\mathrm{R}}$ was detected with an LCR meter operating with an alternating current ( $1 \mathrm{~V}, 1 \mathrm{kHz} \mathrm{AC})$, connected to ground and plant electrodes embedded in the soil and inserted into the plant stem, respectively.

Capacitance is formed by the dielectric polarization of root cell membranes, which induces changes in the magnitude and phase of AC (Repo et al. 2000). The initial model for $C_{\mathrm{R}}$ measurement, developed by Dalton (1995), considers roots as cylindrical capacitors connected in parallel, where the root membranes act as a dielectric, separating the conductive root sap from the conductive soil solution. AC is thought to flow axially in xylem and phloem vessels and 
Table 1 Nomenclature

\begin{tabular}{ll}
\hline Symbol & Meaning \\
\hline AC & Alternating current \\
$C$ & Electrical capacitance \\
$C_{\mathrm{R}}$ & Electrical capacitance of root-substrate system \\
$C_{\mathrm{S}}$ & Electrical capacitance of substrate \\
$\mathrm{Chl}$ & Chlorophyll \\
$\mathrm{ECe}$ & Electrical conductivity of the saturated soil extract \\
$F_{0}$ & Initial Chl $a$ fluorescence \\
$F_{\mathrm{m}}$ & Maximum Chl $a$ fluorescence \\
$F_{\mathrm{v}}$ & Variable Chl $a$ fluorescence \\
$G$ & Electrical conductance \\
$G_{\mathrm{R}}$ & Electrical conductance of root-substrate system \\
$G_{\mathrm{S}}$ & Electrical conductance of substrate \\
$\mathrm{GLA}$ & Green leaf area \\
$\mathrm{MSI}$ & Membrane stability index \\
PS II & Photosystem II \\
$R$ & Electrical resistance \\
RDM & Root dry mass \\
SDM & Shoot dry mass \\
$X$ & Reactance \\
$\hat{Z}$ & Complex electrical impedance \\
$\varepsilon_{\mathrm{r}}$ & Relative permittivity \\
$\Phi$ & Impedance phase angle \\
$\Phi_{\mathrm{R}}$ & Impedance phase angle in root-substrate system \\
$\Phi_{\mathrm{S}}$ & Angular frequency \\
$\omega$ &
\end{tabular}

radially through the root cortex; the capacitance exhibited on the root-soil interface $\left(C_{\mathrm{R}}\right)$ is directly related to the amount of electric charges stored on the membranes. A more recent model by Dietrich et al. (2013) assumed the capacitance of unbranched root segments and of the whole root system to be connected in series and in parallel, respectively. In contrast with Dalton's model, which considers the soil solution as purely conductive, Rajkai et al. (2005) and Dietrich et al. (2013) highlighted the fact that rooting substrates also provide capacitance $\left(C_{\mathrm{S}}\right)$. They proposed the "two-dielectric capacitor model", which contains a root and a soil dielectrics connected serially and have different relative permittivities $\left(\varepsilon_{\mathrm{r}}\right)$. According to physical laws, if the capacitance of the root tissue is considerably smaller than the substrate capacitance, the $C_{\mathrm{R}}$ is determined by the root tissue.

One serious drawback of the capacitance method is that $C_{\mathrm{R}}$ is strongly influenced by soil conditions (water saturation, texture, and chemical composition) and plant electrode placement (Ellis et al. 2013; Cseresnyés et al. 2017), so measurement data are only comparable if the same plant species is grown and measured under the same conditions (Chloupek et al. 2010). However, if the rooting substrate and electrode application procedure are standardized, the method is able to provide a reliable estimation of root system size in pot cultures and occasionally under field conditions (Heřmanská et al. 2015; Postic and Doussan 2016). An outstanding advantage of the technique is that $C_{\mathrm{R}}$ data indicate the activity or "functional extent" of the root system (Dalton 1995; Cseresnyés et al. 2016), as AC predominantly flows through the water-absorbing surfaces of non-suberized fine roots (Čermák et al. 2006).

When AC is driven through a circuit element, complex impedance $(\hat{Z})$ is generated. The common equation to describe complex impedance is: $\hat{Z}=Z^{\prime}+j Z^{\prime \prime}=|\hat{Z}| e^{j \Phi}$, where $Z^{\prime}$ and $Z^{\prime \prime}$ are the real parts (resistance; $Z^{\prime}=R$ ) and the imaginary part (reactance; $Z^{\prime \prime}=X$ ), respectively, and $j$ is the imaginary unit $\left(j^{2}=-1\right)$. According to the equation, $\hat{Z}$ can also be characterized by the magnitude, $|\hat{Z}|$ (the ratio of the voltage amplitude to the current amplitude) and the phase angle, $\Phi$ (the phase shift between total voltage and total electric current). At any $\mathrm{AC}$ frequency, $\Phi=0^{\circ}$ and $\Phi=-90^{\circ}$ for ohmic resistors and ideal (lossless) capacitors, respectively (negative $\Phi$ indicates that current leads the voltage). Living tissues are lossy capacitors, which-in accordance with Dalton's model-are parallel circuits of resistances, $R$, and capacitances, $C$ (Grimnes and Martinsen 2015). Cell membranes represent the main capacitive component, whereas the extracellular matrix and cytoplasm are mainly resistive (Li et al. 2017). The phase angle of the root-substrate system $\left(\Phi_{\mathrm{R}}\right)$ is much smaller (in absolute value) than $90^{\circ}$, and depends on the current frequency, soil type, and plant species (Cseresnyés et al. 2017), as well as being influenced by the physicochemical properties of root tissues (Aubrecht et al. 2006). Modeling the root system by a parallel RC circuit, the relationship between complex impedance and capacitance is: $1 / \hat{Z}=1 / R+j \omega C_{\mathrm{R}}$, where $\omega$ is the angular frequency. It is worth emphasizing that the $R$ is here used as the real part of the $\hat{Z}$, contrasting the widespread use of the term "resistance/resistivity" with regard to the method of electrical resistivity tomography, ERT (Weigand and Kemna 2019), where the magnitude of the impedance is referred to as resistance $(R=|\hat{Z}|)$.

Environmental stress is reported to cause changes in the electrical properties of plant tissues by modifying numerous features of cell walls, membranes, and the cytosol (Jócsák et al. 2010; Khaled et al. 2018). For this reason, impedance spectroscopy has become an effective method to study plant responses to, e.g., freeze injury, high salinity, or nutrient stress at the cellular level, using a wide frequency range $(\mathrm{Hz}-\mathrm{MHz})$ in isolated tissues and organs (Repo et al. 2000; Hamed et al. 2016; Li et al. 2017).

By measuring the impedance components and considering the root-substrate system as a parallel RC circuit, its electrical conductance ( $G$, the reciprocal of the resistance) can be calculated as $G_{\mathrm{R}}=\tan \left(90-\Phi_{\mathrm{R}}\right)^{\circ} \times \omega \times C_{\mathrm{R}}$. Wet soils have 2-3 orders of magnitude higher electrical conductance 
than root systems, so $G_{\mathrm{R}}$ is determined by the root conductance (Cseresnyés et al. 2017). The magnitude of root conductance depends not only on the root system size, but also on the composition of the electrolytes and the integrity and permeability of the membranes (Aubrecht et al. 2006), thus providing useful information about root status.

The present study aimed to show that the monitoring of electrical parameters, such as capacitance $\left(C_{\mathrm{R}}\right)$, impedance phase angle $\left(\Phi_{\mathrm{R}}\right)$, and conductance $\left(G_{\mathrm{R}}\right)$, in intact root-substrate systems at a single low $(1 \mathrm{kHz})$ frequency gives useful insights into some aspects of root development in pot cultures. As far as we know, this is the first combined application of these parameters to investigate plant root status in situ. The approach is now applied to evaluate the response of roots to different levels of substrate alkalinity. The genotypic differences in root growth and stress tolerance were also studied using two wheat cultivars in the experiment. Other physiological investigations were carried out in potted plants to verify that the electrical characterization of the root system was an effective complementary technique to the widely used plant methods.

\section{Materials and methods}

\section{Plant material and cultivation}

The pot experiment consisted of a factorial design $(n=10)$ with two wheat cultivars [Triticum aestivum L. cv. Hombar $(H)$ and cv. TC33 $(T)]$ and four alkaline treatments, namely control (0), and low (1), medium (2), and high (3) salt levels with 1,2 , and $3 \mathrm{~g} \mathrm{Na}_{2} \mathrm{CO}_{3} \mathrm{~kg}^{-1}$ substrate, respectively. The substrate $\mathrm{pH}$ under alkaline stress was 8.58, 9.45, and 10.12 with corresponding ECe of 2.62, 4.18, and $5.27 \mathrm{dS} \mathrm{m}^{-1}$.

The seeds were germinated on moistened filter papers in Petri dishes at $23{ }^{\circ} \mathrm{C}$ for 2 days in darkness, after which the seedlings were planted into $0.85 \mathrm{dm}^{3}$ plastic pots filled with $0.5 \mathrm{~kg}$ of a $1: 1(\mathrm{v} / \mathrm{v})$ mixture of $0-5 \mathrm{~mm}$ rhyolite (Colas Co. Ltd., Tarcal, Hungary) and vermiculite (Pull Rhenen B. V., Rhenen, The Netherlands). The substrate had a $\mathrm{pH}_{\mathrm{H} 2 \mathrm{O}}$ of 7.47 , bulk density of $0.67 \mathrm{~kg} \mathrm{dm}^{-3}$, CEC of $9.13 \mathrm{mmol}$ $100 \mathrm{~g}^{-1}$, and $0.39 \mathrm{~cm}^{3} \mathrm{~cm}^{-3}$ water content at field capacity. Prior to planting, each pot was irrigated with $250 \mathrm{~cm}^{3}$ of distilled water (control plants) or saline solution containing the required amount of $\mathrm{Na}_{2} \mathrm{CO}_{3}$ (stressed plants). Two seedlings were planted $1 \mathrm{~cm}$ deep in each pot, then fifth days after planting (DAP), they were thinned to one to obtain uniform plant populations. The plants were randomly arranged in a growth room and cultivated for 40 days at $26 / 18^{\circ} \mathrm{C}$ day/ night temperature, $16 \mathrm{~h}$ light period $\left(\sim 600 \mu \mathrm{mol} \mathrm{m}^{-2} \mathrm{~s}^{-1}\right.$ PAR) and 50-70\% relative humidity. The pots were irrigated daily with tap water to field capacity after weighing, after which the volumetric moisture content was checked with a Trime-HD2 TDR meter (IMKO GmbH., Ettlingen, Germany) calibrated to the substrate mixture. The plants were fed weekly with $50 \mathrm{~cm}^{3}$ of $3 \times$ Hoagland's solution.

\section{Electrical measurements}

The impedance response of the root-substrate system was measured on four occasions (DAP 12, 20, 30, and 40) with a GW-8101G precision LCR device (GW Instek Co. Ltd., Taiwan) at $1000 \mathrm{~Hz}$ and $1 \mathrm{~V} \mathrm{AC.} C_{\mathrm{R}}, \Phi_{\mathrm{R}}$, and $G_{\mathrm{R}}$ values for the parallel RC circuit were displayed. The ground electrode was a sharpened stainless steel rod $(15 \mathrm{~cm}$ long and $0.6 \mathrm{~cm}$ diameter) inserted to $10 \mathrm{~cm}$ depth in the substrate, $5 \mathrm{~cm}$ away from the stem. The plant electrode was clamped to the stem at precisely $1 \mathrm{~cm}$ above the substrate level through a $0.5 \mathrm{~cm}$ wide aluminum strip that bent the stem (Cseresnyés et al. 2016). Conductivity gel (Vascotasin ${ }^{\circledR}$; Spark Promotions Co. Ltd., Budapest, Hungary) was smeared under the strip to maintain good electric contact (Rajkai et al. 2005). Two hours before electrical measurements, the pots were watered to field capacity (checked with TDR meter). Before seedling planting, the impedance response of the substrate $\left(C_{\mathrm{S}}, \Phi_{\mathrm{S}}\right.$, and $\left.G_{\mathrm{S}}\right)$ was also measured between two identical ground electrodes (with $5 \mathrm{~cm}$ distance).

\section{Chlorophyll fluorescence and leaf chlorophyll content}

The quantum efficiency of photosystem II (PS II) and the leaf chlorophyll (Chl) content were determined on the youngest fully expanded leaf of each plant on DAP 38 (9:00-12:00 a.m.). The fluorescence of $\mathrm{Chl} a$ was detected with an OS$30 \mathrm{p}+$ handheld Chl fluorometer (Opti-Sciences Inc., Hudson, NH, USA). The leaves were first adapted to dark for 10 min using black plastic clamps ( $9 \mathrm{~mm}$ diameter) to record the initial Chl $a$ fluorescence $\left(F_{0}\right)$ and then were exposed to a $1.0 \mathrm{~s}$ saturation pulse of $3000 \mu \mathrm{mol}$ photons $\mathrm{m}^{-2} \mathrm{~s}^{-1}$ to determine the maximum Chl $a$ fluorescence $\left(F_{\mathrm{m}}\right)$. Based on the data obtained, the variable fluorescence $\left(F_{\mathrm{v}}=F_{\mathrm{m}}-F_{0}\right)$ and the maximal efficiency of the PS II center $\left(F_{\mathrm{v}} / F_{\mathrm{m}}\right)$ were calculated for each leaf.

The leaf Chl content was estimated non-destructively, using a Minolta SPAD-502 m (Konica Minolta Inc., Osaka, Japan). A mean SPAD value was calculated from six measurements taken on the same leaf.

\section{Plant harvest and biomass measurement}

All the plants were harvested after the last electrical measurement (DAP 40) by cutting the shoots at the substrate surface. The leaves were detached from the stems and were scanned (Delta-T Deviced Ltd., Cambridge, UK) to estimate green leaf area (GLA). Roots were washed carefully by hand 
with running water over a sieve $(0.2 \mathrm{~mm})$ to remove substrate followed by the flotation of roots (Oliveira et al. 2000). The root surface was quickly dried with paper towels and the roots were weighed $( \pm 0.001 \mathrm{~g})$. A sample was taken from each root for the assessment of membrane stability index (MSI; see below), and the roots were instantly reweighed. The shoots (combined stems and leaves) and roots were oven-dried $\left(70{ }^{\circ} \mathrm{C}\right)$ to constant mass and weighed to obtain shoot dry mass (SDM) and root dry mass (RDM).

\section{Membrane stability index}

MSI was determined from $0.1 \mathrm{~g}$ root samples, consisting of randomly selected fine roots, according to the method of Sairam et al. (2002). The samples were rinsed three times with double-distilled water (to completely remove the adsorbed $\mathrm{Na}^{+}$ions) and put in test tubes containing $10 \mathrm{~cm}^{3}$ of double-distilled water. The tubes were kept in a water bath at $40{ }^{\circ} \mathrm{C}$ for $30 \mathrm{~min}$, and then cooled to $20^{\circ} \mathrm{C}$. The electrical conductivity $\left(\mathrm{EC}_{1}\right)$ of the water was recorded using a MultiLine-P4 device with TetraCon 325 conductivity cell (WTW GmbH, Weilheim, Germany). The tubes were incubated at $95{ }^{\circ} \mathrm{C}$ for $15 \mathrm{~min}$ and then cooled to $20{ }^{\circ} \mathrm{C}$, and conductivity was measured again $\left(\mathrm{EC}_{2}\right)$. MSI was calculated as: $\mathrm{MSI}=\left[1-\left(\mathrm{EC}_{1} / \mathrm{EC}_{2}\right)\right] \times 100$.

\section{Data analysis}

The data were analyzed with Statistica software (ver. 13, StatSoft Inc., OK, USA). The unpaired $t$ test or one-way ANOVA and Tukey's post hoc test were used to compare data groups. If the $F$ test or Bartlett test indicated significantly different standard deviations, Welch's $t$ test or the Kruskal-Wallis test with Dunn's post hoc test was applied. Simple regression analysis was used to relate $C_{\mathrm{R}}$ to RDM. Differences in regression line intercepts and slopes for the wheat cultivars were tested by linear analysis of covariance. In each case, differences were accepted as significant at $P<0.05$

\section{Results}

\section{Electrical properties}

Substrate measurements showed relatively large capacitance $\left(C_{\mathrm{S}}\right)$ and predominantly ohmic impedance with a very low phase angle $\left(\left|\Phi_{S}\right|\right.$; Table 2$)$. High alkalinity significantly increased $C_{\mathrm{S}}$ and decreased $\left|\Phi_{\mathrm{S}}\right| G_{\mathrm{S}}$ values measuring a few $\mathrm{mS}$ were detected, which were increased by medium and high salt concentration.

In each treatment, $C_{\mathrm{R}}$ increased consistently with plant age, as the root system expanded (Fig. 1a). Alkalinity
Table 2 Effect of various alkalinity levels $(0,1,2$, or $3 \mathrm{~g}$ $\mathrm{Na}_{2} \mathrm{CO}_{3} \mathrm{~kg}^{-1}$ substrate) on the electrical capacitance $\left(C_{\mathrm{S}}\right)$, impedance phase angle $\left(\Phi_{\mathrm{S}}\right)$, and electrical conductance $\left(G_{\mathrm{S}}\right)$ of the plant growth substrate

\begin{tabular}{llll}
\hline $\begin{array}{l}\text { Alkalinity } \\
\text { level }\end{array}$ & $\begin{array}{l}C_{\mathrm{S}}(\mathrm{nF}) \\
(\text { mean } \pm \mathrm{SD})\end{array}$ & $\begin{array}{l}\Phi_{\mathrm{S}}\left(^{\circ}\right) \\
(\text { mean } \pm \mathrm{SD})\end{array}$ & $\begin{array}{l}G_{\mathrm{S}}(\mathrm{mS}) \\
(\text { mean } \pm \mathrm{SD})\end{array}$ \\
\hline 0 & $18.93 \pm 1.65 \mathrm{a}$ & $-2.40 \pm 0.17 \mathrm{a}$ & $2.84 \pm 0.34 \mathrm{a}$ \\
1 & $19.07 \pm 1.74 \mathrm{a}$ & $-2.36 \pm 0.21 \mathrm{a}$ & $2.91 \pm 0.40 \mathrm{ab}$ \\
2 & $20.11 \pm 1.62 \mathrm{ab}$ & $-2.28 \pm 0.19 \mathrm{ab}$ & $3.18 \pm 0.35 \mathrm{bc}$ \\
3 & $20.81 \pm 1.83 \mathrm{~b}$ & $-2.24 \pm 0.18 \mathrm{~b}$ & $3.35 \pm 0.38 \mathrm{c}$ \\
\hline
\end{tabular}

Lowercase letters indicate groups distinguished by the Tukey post hoc test $(P<0.05 ; n=20)$

caused a significant reduction in $C_{\mathrm{R}}$ (Table 3 ), and the rate of decrease was related to stress level. At the last measurement, the influence of low salt level on $C_{\mathrm{R}}$ became insignificant in comparison to the control for both wheat cultivars. At the first measurement time (DAP 12), significantly (9-11\%) higher mean $C_{\mathrm{R}}$ was detected for $H O$ and $H I$ plants than for the $T O$ and $T 1$ groups, respectively (Table 4), whereas we revealed no cultivar differences on DAP 20 and 30 . The last measurement (DAP 40) showed 11-18\% higher $C_{\mathrm{R}}$ for cultivar $T$ compared with $H$, except under high alkalinity, where the difference proved to be insignificant.

$\left|\Phi_{R}\right|$ reached a maximum value on DAP 20 for nonstressed plants and at low alkaline level, but decreased continuously during the whole growing period in plants exposed to medium or high alkalinity (Fig. 1b). On DAP $12,\left|\Phi_{\mathrm{R}}\right|$ was only significantly reduced by the high stress level, but later (DAP 20 and 30) even by the medium level. At the last measurement, $\left|\Phi_{\mathrm{R}}\right|$ was lower in all the stress treatments for cultivar $H$, but only under high alkalinity for cultivar $T$ compared to the respective control. The cultivars showed no differences in $\left|\Phi_{\mathrm{R}}\right|$ up to DAP 40, when its value became higher for cultivar $T$ grown under stress.

As the plants grew, there was a continuous increase in $G_{\mathrm{R}}$, irrespective of the alkaline treatment (Fig. 1c). The first measurement showed a significant (15-22\%) reduction in $G_{\mathrm{R}}$ for both cultivars when subjected to high salt content. Thereafter, no differences were found between the treatments, except for $\mathrm{HO}$ vs. $\mathrm{H3}$ on DAP 30. Cultivar differences in $G_{\mathrm{R}}$ proved to be insignificant except on DAP 12, when $H 1$ plants exhibited higher values than $T 1(P=0.034)$.

\section{$F_{\mathrm{v}} / F_{\mathrm{m}}$ and leaf $\mathrm{Chl}$ content}

The $F_{\mathrm{v}} / F_{\mathrm{m}}$ value in the youngest fully expanded leaves was unaffected by low and medium alkalinity, but significantly decreased by the high stress level (Fig. 2a). Under nonstressed conditions, cultivar $H$ exhibited a higher $(P=0.036)$ 
Fig. 1 Changes in a electrical capacitance $\left(C_{\mathrm{R}}\right)$, b impedance phase angle $\left(\Phi_{\mathrm{R}}\right)$, and $\mathbf{c}$ electrical conductance $\left(G_{\mathrm{R}}\right)$ of the root-substrate system measured at different plant ages (days after planting, DAP) in two wheat cultivars $(H$ and $T)$ exposed to various levels of alkalinity stress $(0,1,2$, or $3 \mathrm{~g}$ $\mathrm{Na}_{2} \mathrm{CO}_{3} \mathrm{~kg}^{-1}$ substrate). Error bars represent $\mathrm{SD}(n=10)$. Phase angle graph is shown with inverted vertical axis, as a higher negative $\Phi$ value indicates a higher phase angle in capacitors
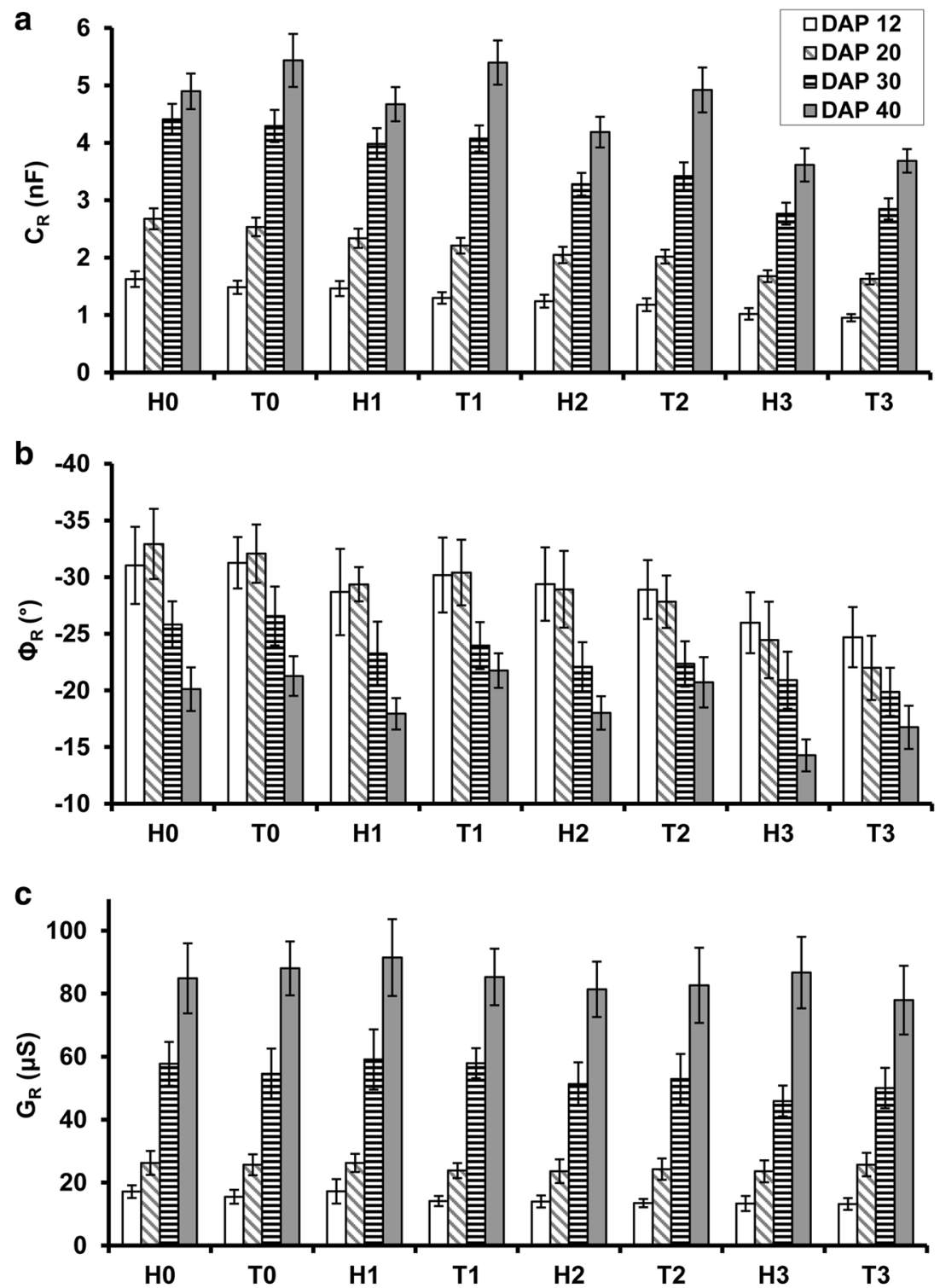

$\mathrm{F}_{\mathrm{v}} / \mathrm{F}_{\mathrm{m}}$ ratio than cultivar $T$, but the difference was insignificant in the case of stressed plants.

The mean SPAD value of cultivar $H$ proved to be independent of substrate alkalinity, whereas it was significantly reduced (by $8.3 \%$ ) when cultivar $T$ was exposed to the high stress level (Fig. 2b). Irrespective of the growth conditions, the SPAD readings were significantly (16-20\%) lower in cultivar $H$ than in $T$.

\section{Green leaf area and plant biomass}

Mean GLA showed a decreasing trend with increasing alkalinity (Fig. 2c), but the change was only significant in the case of the medium and high alkaline treatments (18\% and $42 \%$, respectively) for cultivar $H$, and only in the case of high stress (43\%) for cultivar $T$. We showed only insignificant differences in GLA between the two cultivars.

Low-dose alkaline stress did not affect the SDM values of the cultivars (Fig. 2d). Compared to the control, SDM was reduced by $16 \%$ and $19 \%$ in cultivars $H$ and $T$, respectively, by the medium alkaline level, and by $35 \%$ and $51 \%$ by high alkalinity. Cultivar $T$ produced significantly higher SDM than cultivar $H$, except when the high alkaline level was applied.

Compared to non-stressed conditions, RDM did not change significantly at low alkalinity (Fig. 2e), but decreased at the medium alkaline level by $16 \%$ and $17 \%$ in cultivars $H$ and $T$, respectively. When the plants were grown at high salt content, the percentage decrease in RDM was $31 \%$ in cultivar $H$ and $48 \%$ in cultivar $T$. Apart from the high alkalinity 
Table 3 Effect of various levels of alkalinity stress $(1,2$, or $3 \mathrm{~g} \mathrm{Na}_{2} \mathrm{CO}_{3} \mathrm{~kg}^{-1}$ substrate) on the parameters of two wheat cultivars $(H$ and $T)$ compared to the control plants $(H O$ or $T O)$
Table 4 Differences between the parameters of wheat cultivars $H$ and $T$ for plants grown under various levels of alkalinity stress $(0,1,2$ or $3 \mathrm{~g}$ $\mathrm{Na}_{2} \mathrm{CO}_{3} \mathrm{~kg}^{-1}$ substrate)

\begin{tabular}{|c|c|c|c|c|c|c|c|}
\hline \multirow[t]{3}{*}{ Parameter } & \multirow{3}{*}{$\begin{array}{l}\text { Plant age, DAP (days } \\
\text { after planting) }\end{array}$} & \multicolumn{6}{|c|}{ Treatments compared } \\
\hline & & \multicolumn{3}{|c|}{ H0 vs. } & \multicolumn{3}{|c|}{ T0 vs. } \\
\hline & & H1 & $\mathrm{H} 2$ & H3 & $\mathrm{T} 1$ & $\mathrm{~T} 2$ & T3 \\
\hline \multirow[t]{4}{*}{$C_{\mathrm{R}}$} & 12 & $*$ & $* * *$ & $* * *$ & $* *$ & $* * *$ & $* * *$ \\
\hline & 20 & $* * *$ & $* * *$ & $* * *$ & $* * *$ & $* * *$ & $* * *$ \\
\hline & 30 & $* * *$ & $* * *$ & $* * *$ & NS & $* * *$ & $* * *$ \\
\hline & 40 & NS & $* * *$ & $* * *$ & NS & $*$ & $* * *$ \\
\hline \multirow[t]{4}{*}{$\Phi_{\mathrm{R}}$} & 12 & NS & NS & $* * *$ & NS & NS & $* * *$ \\
\hline & 20 & $*$ & $*$ & $* * *$ & NS & $* *$ & $* * *$ \\
\hline & 30 & NS & $* *$ & $* * *$ & NS & $* * *$ & $* * *$ \\
\hline & 40 & $*$ & $*$ & $* * *$ & NS & NS & $* * *$ \\
\hline \multirow[t]{4}{*}{$G_{\mathrm{R}}$} & 12 & NS & NS & $*$ & NS & NS & $*$ \\
\hline & 20 & NS & NS & NS & NS & NS & NS \\
\hline & 30 & NS & NS & $*$ & NS & NS & NS \\
\hline & 40 & NS & NS & NS & NS & NS & NS \\
\hline$F_{\mathrm{v}} / F_{\mathrm{m}}$ & 38 & NS & NS & $* * *$ & NS & NS & $*$ \\
\hline Chl (SPAD value) & 38 & $\mathrm{NS}^{\mathrm{a}}$ & $\mathrm{NS}^{\mathrm{a}}$ & $\mathrm{NS}^{\mathrm{a}}$ & NS & NS & * \\
\hline GLA & 40 & NS & $*$ & $* * *$ & NS & NS & $* * *$ \\
\hline SDM & 40 & NS & $*$ & $* * *$ & NS & $* *$ & $* * *$ \\
\hline RDM & 40 & NS & $* * *$ & $* * *$ & NS & $* * *$ & $* * *$ \\
\hline MSI & 40 & NS & NS & $*$ & $* * *$ & $* * *$ & $* * *$ \\
\hline
\end{tabular}

One-way ANOVA with the Tukey post hoc test $(n=10)$

$N S$ non-significant

$* P<0.05, * * P<0.01, * * * P<0.001$

${ }^{a}$ Kruskal-Wallis test with Dunn's post hoc test

\begin{tabular}{|c|c|c|c|c|c|}
\hline \multirow[t]{2}{*}{ Parameter } & \multirow{2}{*}{$\begin{array}{l}\text { Plant age, DAP (days } \\
\text { after planting) }\end{array}$} & \multicolumn{4}{|c|}{ Treatments compared } \\
\hline & & H0 vs. T0 & H1 vs. T1 & $\mathrm{H} 2$ vs. T2 & $\mathrm{H} 3$ vs. T3 \\
\hline \multirow[t]{4}{*}{$C_{\mathrm{R}}$} & 12 & $*$ & $* *$ & NS & NS \\
\hline & 20 & NS & NS & NS & NS \\
\hline & 30 & NS & NS & NS & NS \\
\hline & 40 & $* *$ & $* * *$ & $* * *$ & NS \\
\hline \multirow[t]{4}{*}{$\Phi_{\mathrm{R}}$} & 12 & NS & NS & NS & NS \\
\hline & 20 & NS & $\mathrm{NS}^{\mathrm{a}}$ & NS & NS \\
\hline & 30 & NS & NS & NS & NS \\
\hline & 40 & NS & $* * *$ & $* *$ & $* *$ \\
\hline \multirow[t]{4}{*}{$G_{\mathrm{R}}$} & 12 & NS & $*$ & NS & NS \\
\hline & 20 & NS & NS & NS & NS \\
\hline & 30 & NS & NS & NS & NS \\
\hline & 40 & NS & NS & NS & NS \\
\hline$F_{\mathrm{v}} / F_{\mathrm{m}}$ & 38 & $*$ & NS & NS & NS \\
\hline Chl (SPAD value) & 38 & $* * *$ & $* * *$ & $* * *$ & $* *$ \\
\hline GLA & 40 & NS & NS & NS & NS \\
\hline SDM & 40 & $* *$ & $* * *$ & $*$ & NS \\
\hline $\mathrm{RDM}$ & 40 & $* * *$ & $* * *$ & $* * \mathrm{a}$ & NS \\
\hline MSI & 40 & $\mathrm{NS}^{\mathrm{a}}$ & $\mathrm{NS}^{\mathrm{a}}$ & $\mathrm{NS}^{\mathrm{a}}$ & $* *$ \\
\hline
\end{tabular}

Unpaired $t$ test $(n=10)$

$N S$ non-significant

$* P<0.05, * * P<0.01, * * * P<0.001$

${ }^{a}$ Welch's $t$ test 
Fig. 2 a Photochemical efficiency $\left(F_{\mathrm{v}} / F_{\mathrm{m}}\right)$ and $\mathbf{b}$ chlorophyll content (in SPAD value) of the youngest fully expanded leaves, $\mathbf{c}$ green leaf area (GLA), d shoot dry mass (SDM), e root dry mass (RDM), and f root membrane stability index (MSI) measured in two wheat cultivars $(H$ and $T$ ) exposed to various levels of alkalinity stress $(0,1,2$ or $3 \mathrm{~g} \mathrm{Na}_{2} \mathrm{CO}_{3} \mathrm{~kg}^{-1}$ substrate).

Error bars represent SD $(n=10)$
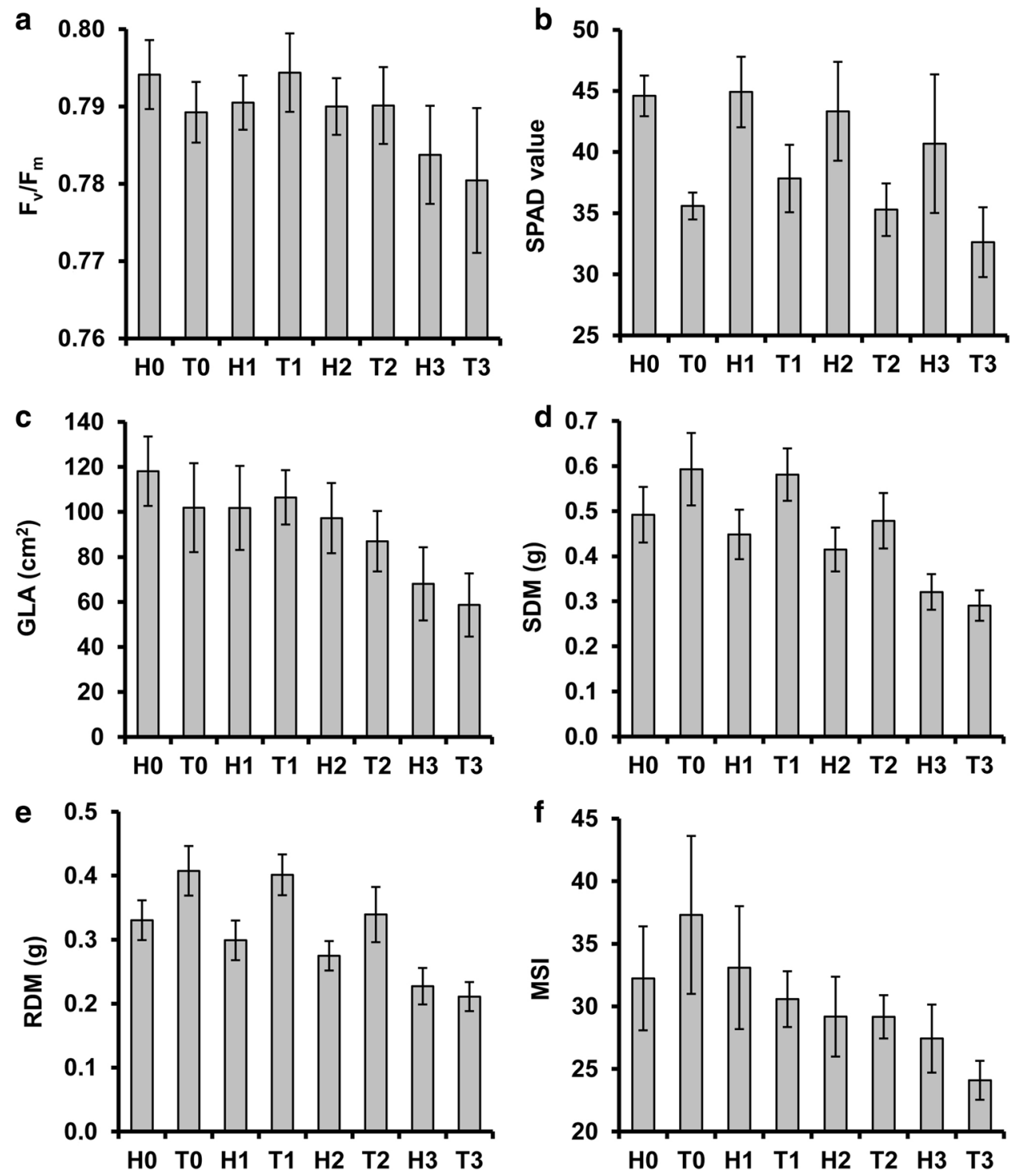

treatment, the RDM of cultivar $T$ proved to be significantly higher than that of cultivar $H$.

\section{Membrane stability index}

The root MSI declined in response to increasing alkalinity level (Fig. 2f). The stress effect was more pronounced for cultivar $T$, in which MSI was significantly reduced by any salt treatment, while in cultivar $H$, only high alkalinity induced a significant decline in membrane stability. For this reason, MSI was significantly lower for cultivar $T$ than for $H$ when high alkalinity level was applied.

\section{Root capacitance-root dry mass regressions}

A close linear relationship $(P<0.001 ; n=40)$ was found between $C_{\mathrm{R}}$ and RDM for both cultivar $H\left(R^{2}=0.883\right)$ and $T\left(R^{2}=0.940\right.$; Fig. 3$)$. Linear analysis of covariance showed that the slope of the regression line for cultivar $H$ $\left(11.44 \pm 0.68 \mathrm{nF} \mathrm{g}^{-1} \mathrm{RDM}\right.$; mean $\left.\pm \mathrm{SE}\right)$ was significantly $(P=0.002)$ steeper and the $y$-intercept $(1.11 \pm 0.19 \mathrm{nF})$ significantly $(P=0.003)$ smaller than for cultivar $T$ $\left(8.95 \pm 0.37 \mathrm{nF} \mathrm{g}^{-1} \mathrm{RDM} ; 1.82 \pm 0.13 \mathrm{nF}\right)$.

\section{Discussion}

The electrical measurements demonstrated that substrate capacitance $\left(C_{\mathrm{S}}\right)$ and conductance $\left(G_{\mathrm{S}}\right)$ were substantially higher than the values recorded in root-substrate systems $\left(C_{\mathrm{R}}\right.$ and $G_{\mathrm{R}}$ ). These findings corroborated the assumptions both of Dalton's (1995) model and of the two-dielectric capacitor model, implying that $C_{\mathrm{R}}$ and $G_{\mathrm{R}}$ are determined 
Fig. 3 Linear relationship between the electrical capacitance of the root-substrate system $\left(C_{\mathrm{R}}\right)$ and the root dry mass (RDM) of wheat cultivars $H$ (filled triangle, solid line) and $T$ (unfilled circle, dashed line) exposed to various levels of alkalinity stress. Regressions are significant at the $P<0.001$ level $(n=40)$. Analysis of covariance showed significant differences between the slope $(P=0.002)$ and $y$-intercept $(P=0.003)$ of the regressions

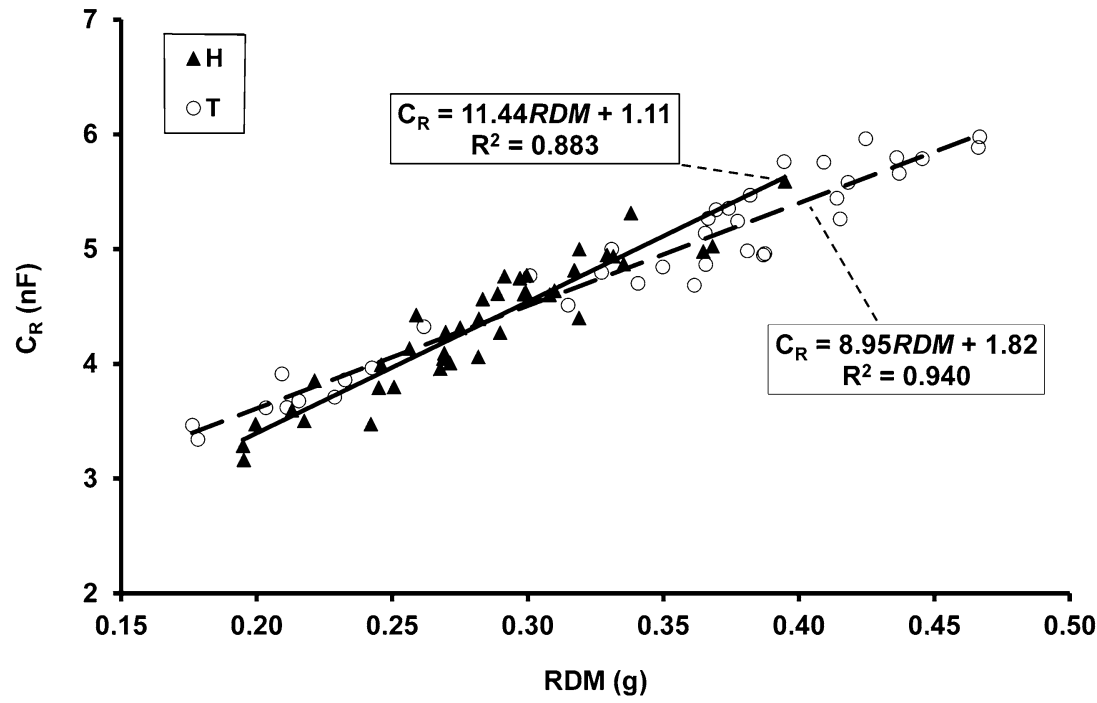

by the root capacitance and root conductance. On this basis, it is very likely that the relatively slight further increment in $C_{\mathrm{S}}$ and $G_{\mathrm{S}}$ after salt addition had a negligible effect on measurements in the root-substrate system.

Saline conditions impose multiple stresses on roots, including osmotic and oxidative stress, or specific ion toxicity (Bernstein 2013; Gupta and Huang 2014). Alkaline salts cause more harmful effects than neutral salts due to the elevated $\mathrm{pH}$, which destroys the nutrient supply and results in serious ion imbalance (Yang et al. 2008). The rhizodermal cell membrane provides various mechanisms for acclimation to adverse environmental conditions. Exposure to high salinity affects ion uptake processes and alters the membrane potential (Suhayda et al. 1990). Salinization markedly modifies membrane protein and lipid composition, inducing changes in membrane structure, and disrupting integrity and selectivity (López-Pérez et al. 2009). The enhanced formation of reactive oxygen species causes cell damage, e.g., membrane lipid peroxidation (Gupta and Huang 2014). Salt stress stimulates the maturation of the exodermis and endodermis and the development of the Casparian strip (Hose et al. 2001). Typical responses of roots to saline-alkaline conditions are an increased rate of lignification and suberization, and enhanced amounts of lignin and suberin, accompanied by altered chemical composition. Salt-induced cell death and restricted cell division are reported to result in shorter but thicker root branches (Bernstein 2013). Impeded root growth is also due to the adverse effect of alkaline salts on substrate (soil) properties, such as $\mathrm{pH}$, hydraulic conductivity, or redox potential, related to nutrient deficiency and toxicity (Wright and Rajper 2000).

The aforementioned physicochemical, histological, and morphological changes are jointly responsible for the altered electrical properties of root tissues, which are reflected in the modified impedance response of the root-substrate system.
The reduced root growth rate was clearly indicated by the decreasing $C_{\mathrm{R}}$ reading at increasing salt stress levels. Alterations in root morphology and architecture also contribute to the decline in $C_{\mathrm{R}}$ : though salinity tends to promote the formation of adventitious roots, the extensive degradation of root hairs leads to a reduction in the charge-storage (ionabsorbing) root surface area and thus in $C_{\mathrm{R}}$ (Dalton 1995; Ellis et al. 2013).

The present results show that alkalinity also decreased the efficiency of charge storage $\left(\left|\Phi_{\mathrm{R}}\right|\right)$. Low-frequency AC passes through the root primarily through the apoplastic (extracellular) pathway, which is almost purely resistive, and only to a lesser extent through the symplastic (intracellular) pathway, which contains capacitive elements, such as cell membranes ( $\mathrm{Li}$ et al. 2017). The electrical properties detected for roots depend on the contribution of these parallel pathways to $\hat{Z}$ (Repo et al. 2000; Khaled et al. 2018). Stress-induced changes in root membranes, particularly enhanced lignin and suberin content, modify the ratio of the current pathways, and thus the dielectric response of the roots. Lignin and suberin are electrical insulators, possessing lower relative permittivity $\left(\varepsilon_{\mathrm{r}}=2-2.4\right)$ compared to other main components of root tissues, i.e. water $\left(\varepsilon_{\mathrm{r}} \sim 80\right)$ or cellulose ( $\varepsilon_{\mathrm{r}} \sim 7.6$; Ellis et al. 2013). Therefore, the increased amount of these materials deposited in cell walls under stress results in reduced $\left|\Phi_{\mathrm{R}}\right|$ and enhanced $R$ in the roots (Jócsák et al. 2010). Stress is observed to weaken the electrical double layers present in the root, decreasing the magnitude of the overall polarization response (Weigand and Kemna 2017). Lignification and suberization are inherent processes in maturing roots, often reflected as declining $\left|\Phi_{R}\right|$ during later stages of ontogeny (Cseresnyés et al. 2018a). However, stress causes an additional decrease in the phase angle, as indicated in the present experiment by the disappearance of 
the peak value of $\left|\Phi_{R}\right|$ at DAP 20 at the medium and high alkalinity levels.

Alkalinity caused no significant reduction in $G_{\mathrm{R}}$, despite the fact that root size (RDM) progressively decreased with increasing salt content, while the intensifying lignification could be expected to form an effective barrier against apoplastic flow of water, ions and electric current (Hose et al. 2001; Aubrecht et al. 2006). This implies a considerable increase in symplastic conductivity (specific conductance) due to the enhanced intracellular $\mathrm{Na}^{+}$concentration and the greater leakage of solutes through the membranes (Yang et al. 2008; Hamed et al. 2016). Increased electrolyte leakage in salt-stressed roots is attributable to the enhanced membrane permeability caused by ROS-induced oxidative damage, as detected on the basis of decreasing MSI (Kumar et al. 2015).

Salt stress generally reduces the leaf Chl content, mainly through the inhibition of $\mathrm{Chl}$ synthesis and destruction in the chloroplast structure, and it causes a decline in PS II efficiency (Mathur et al. 2013; Gupta and Huang 2014). In the present case, $F_{\mathrm{v}} / F_{\mathrm{m}}$ and SPAD measurements only showed this effect in plants subjected to high alkalinity, probably because the investigations were restricted to the youngest fully expanded leaves on each plant. Wheat is known to respond to salinity by the accelerated death of old leaves and by the translocation of nutrients into the younger leaves, contributing to the maintenance of their photosynthetic capacity during stress (Ouerghi et al. 2000). In the present experiment, the senescence of older leaves was greater in stressed plants. Wheat cultivars were reported to exhibit great genetic variance in SPAD readings, due not only to the different $\mathrm{Chl}$ concentrations, but also to the non-uniform Chl distribution pattern and to differences in leaf thickness and mesophyll structure (Giunta et al. 2002; Monostori et al. 2016).

The present results suggest that wheat cultivar $T$ was comparatively sensitive to a high alkaline level, showing a higher percentage reduction in $C_{R}$ (DAP 40), SDM, and RDM over the control plants compared with the changes calculated for cultivar $H$ (the significantly higher $C_{\mathrm{R}}$ and biomass showed by cultivar $T$ in the other treatments became insignificant at high alkalinity). The greater sensitivity of cultivar $T$ to highly alkaline conditions was also indicated by the significantly lower root MSI. This is consistent with reports on studies involving numerous wheat genotypes, which demonstrated that the decrease in MSI caused by salinity stress was correlated with the loss of plant biomass, in association with enhanced membrane lipid peroxidation and intracellular $\mathrm{Na}^{+}$concentration (Sairam et al. 2002; Farooq and Azam 2006; Kumar et al. 2015). The significantly higher $\left|\Phi_{\mathrm{R}}\right|$ measured for the less tolerant cultivar $T$ under alkalinity suggests that smaller changes (moderate lignification rate) were induced in roots for adaptation to adverse conditions.
The histochemical observations reported by Jbir et al. (2001) confirmed a greater increase in cell-wall peroxidase activity and more intense lignification in the central cylinder of root in salt-tolerant than in salt-sensitive wheat species under salinity. However, further experimental approaches will be required to verify the relationship between $\Phi_{\mathrm{R}}$ and the lignin and suberin content of roots.

The strong $C_{\mathrm{R}}-\mathrm{RDM}$ relationships demonstrated that electrical capacitance was a reliable indicator of root system size. Nevertheless, the significantly different regression slopes and intercepts showed that a comparison between cultivars based on $C_{\mathrm{R}}$ measurements should be made cautiously after specific calibration. The observed discrepancies in regression parameters are likely due to different root cross-sectional area, and to differences in root anatomy and morphology (Dietrich et al. 2013). The positive intercept is indicative of the "accompanying capacitance", which is determined by the stem capacitance and also by substrate properties, including water content (Chloupek et al. 2010; Cseresnyés et al. 2017). Root system size can also be estimated by detecting $C_{\mathrm{R}}$ in plants grown in natural soils. However, the dielectric nature of variably charged soil colloids interferes with the root electrical signal, resulting in less reliable measurements (Postic and Doussan 2016; Cseresnyés et al. 2017). Although root electrical characterization is better suited for use in potted plants, promising examples have been reported the estimation of root size and activity based on $C_{\mathrm{R}}$ data recorded with a handheld LCR meter in the field (Chloupek et al. 2010; Heřmanská et al. 2015; Cseresnyés et al. 2018b).

In conclusion, the single-frequency monitoring of electrical capacitance, impedance phase angle, and electrical conductance in root-substrate systems is a beneficial in situ technique for studying root growth and status and the response to abiotic stresses, and for assessing the stress tolerance of cultivars under pot conditions. Without offering a direct insight into the root system, this in situ technique is nevertheless suitable for recording root traits on a fine-time scale, and for the detection of cultivar-specific differences in comparative experiments involving numerous plants. It is particularly useful when plant injury or soil disturbance are unacceptable. The present observations suggest that the electrical characterization method has the potential to complement other plant physiological investigations by providing information about the living root system hidden in the soil, and thus deserves further attention in plant studies.

Author contribution statement ICs designed the study, carried out the electrical measurements, read the relevant literature, and wrote the paper. TT designed the plant physiological investigations and participated in writing the paper. BS cultivated the plants and performed biomass measurements. RK, AF, and IP carried out plant physiological 
measurements and evaluated the data. KR supervised the work and helped in data interpretation. All the authors read the manuscript and approved the submission.

Acknowledgements Open access funding provided by MTA Centre for Agricultural Research (MTA ATK). The project was implemented with the support provided from the National Research, Development and Innovation Fund of Hungary (project no. K-115714, financed under the K-16 funding scheme) and the János Bolyai Research Scholarship of the Hungarian Academy of Sciences (Grant number. BO/00107/18). The authors thank Dr. Maximilian Weigand (University of Bonn) for useful comments and Barbara Harasztos for language editing.

\section{Compliance with ethical standards}

Conflict of interest The authors declare that they have no conflict of interest.

Open Access This article is distributed under the terms of the Creative Commons Attribution 4.0 International License (http://creativeco mmons.org/licenses/by/4.0/), which permits unrestricted use, distribution, and reproduction in any medium, provided you give appropriate credit to the original author(s) and the source, provide a link to the Creative Commons license, and indicate if changes were made.

\section{References}

Aubrecht L, Staněk Z, Koller J (2006) Electrical measurement of the absorption surfaces of tree roots by the earth impedance methods: 1 Theory. Tree Physiol 26:1105-1112. https://doi.org/10.1093/ treephys/26.9.1105

Bernstein N (2013) Effects of salinity on root growth. In: Eshel A, Beeckman T (eds) Plant roots: the hidden half, 4th edn. CRC Press, Boca Raton, pp 1-18

Čermák J, Ulrich R, Staněk Z, Koller J, Aubrecht L (2006) Electrical measurement of tree root absorbing surfaces by the earth impedance method: 2. Verification based on allometric relationships and root severing experiments. Tree Physiol 26:1113-1121. https ://doi.org/10.1093/treephys/26.9.1113

Chloupek O (1972) The relationship between electric capacitance and some other parameters of plant roots. Biol Plant 14:227-230. https ://doi.org/10.1007/BF02921255

Chloupek O, Dostál V, Středa T, Psota V, Dvořáčková O (2010) Drought tolerance of barley varieties in relation to their root system size. Plant Breed 129:630-636. https://doi.org/10.111 1/j.1439-0523.2010.01801.x

Cseresnyés I, Rajkai K, Takács T (2016) Indirect monitoring of root activity in soybean cultivars under contrasting moisture regimes by measuring electrical capacitance. Acta Physiol Plant 38:121. https://doi.org/10.1007/s11738-016-2149-z

Cseresnyés I, Kabos S, Takács T, Végh RK, Vozáry E, Rajkai K (2017) An improved formula for evaluating electrical capacitance using the dissipation factor. Plant Soil 419:237-256. https://doi. org/10.1007/s11104-017-3336-4

Cseresnyés I, Rajkai K, Takács T, Vozáry E (2018a) Electrical impedance phase angle as an indicator of plant root stress. Biosyst Eng 169:226-232. https://doi.org/10.1016/j.biosystems eng.2018.03.004
Cseresnyés I, Szitár K, Rajkai K, Füzy A, Mikó P, Kovács R, Takács T (2018b) Application of electrical capacitance method for prediction of plant root mass and activity in field-grown crops. Front Plant Sci 9:93. https://doi.org/10.3389/fpls.2018.00093

Dalton FN (1995) In-situ root extent measurements by electrical capacitance methods. Plant Soil 173:157-165. https://doi.org/10.1007/ BF00155527

Dietrich RC, Bengough AG, Jones HG, White PJ (2013) Can root electrical capacitance be used to predict root mass in soil? Ann Bot 112:457-464. https://doi.org/10.1093/aob6mct044

Ellis T, Murray W, Paul K, Kavalieris L, Brophy J, Williams C, Maass M (2013) Electrical capacitance as a rapid non-invasive indicator of root length. Tree Physiol 33:3-17. https://doi.org/10.1093/ treephys/tps 115

Farooq S, Azam F (2006) The use of cell membrane stability (CMS) technique to screen for salt tolerant wheat varieties. J Plant Physiol 163:629-637. https://doi.org/10.1016/j.jplph.2005.06.006

Giunta F, Motzo R, Deidda M (2002) SPAD readings and associated leaf traits in durum wheat, barley and triticale cultivars. Euphytica 125:197-205. https://doi.org/10.1023/A:1015878719389

Grimnes S, Martinsen ØG (2015) Bioimpedance and bioelectricity basics, 3rd edn. Elsevier, London, p 584

Gupta B, Huang B (2014) Mechanism of salinity tolerance in plants: physiological, biochemical, and molecular characterization. Int J Genom. https://doi.org/10.1155/2014/701596

Hamed KB, Zorrig W, Hamzaoui AH (2016) Electrical impedance spectroscopy: a tool to investigate the responses of one halophyte to different growth and stress conditions. Comput Electron Agric 123:376-383. https://doi.org/10.1016/j.compag.2016.03.006

Heřmanská A, Středa T, Chloupek O (2015) Improved wheat grain yield by a new method of root selection. Agron Sustain Dev 35:195-202. https://doi.org/10.1007/s13593-014-0227-4

Hose E, Clarkson DT, Steudle E, Schreiber L, Hartung W (2001) The exodermis: a variable apoplastic barrier. J Exp Bot 52:2245-2264. https://doi.org/10.1093/jexbot/52.365.2245

Jbir N, Chaïbi W, Ammar S, Jemmali A, Ayadi A (2001) Root growth and lignification of two wheat species differing in their sensitivity to $\mathrm{NaCl}$, in response to salt stress. CR Acad Sci III-VIE 324:863-868. https://doi.org/10.1016/S0764-4469(01)01355-5

Jócsák I, Droppa M, Horváth G, Bóka K, Vozáry E (2010) Cadmiumand flood-induced anoxia stress in pea roots measured by electrical impedance. Z Naturforsch C 65:95-102. https://doi.org/10.1515/ znc-2010-1-216

Khaled AY, Aziz SA, Bejo SK, Nawi NM, Seman IA, Onwude DI (2018) Early detection of diseases in plant tissue using spectroscopy-applications and limitations. Appl Spectrosc Rev 53:3664. https://doi.org/10.1080/05704928.2017.1352510

Kumar M, Hasan M, Arora A, Gaikwand K, Kumar S, Rai RD, Singh A (2015) Sodium chloride-induced spatial and temporal manifestation in membrane stability index and protein profiles of contrasting wheat (Triticum aestivum L.) genotypes under salt stress. Indian J Plant Physiol 20:271-275. https://doi.org/10.1007/s4050 2-015-0157-4

Li MQ, Li JY, Wei XH, Zhu WJ (2017) Early diagnosis and monitoring of nitrogen nutrition stress in tomato leaves using electrical impedance spectroscopy. Int J Agr Biol Eng 10:194-205. https:// doi.org/10.3965/j.ijabe.20171003.3188

López-Pérez L, Martínez-Ballesta MC, Maurel C, Carvajal M (2009) Changes in plasma membrane lipids, aquaporins and proton pump of broccoli roots, as an adaptation mechanism to salinity. Phytochemistry 70:492-500. https://doi.org/10.1016/j.phyto chem.2009.01.014

Mathur S, Mehta P, Jajoo A (2013) Effect of dual stress (high salt and high temperature) on the photochemical efficiency of wheat leaves (Triticum aestivum). Physiol Mol Biol Pla 19:179-188. https://doi. org/10.1007/s12298-012-0151-5 
Milchunas DG (2012) Biases and errors associated with different root production methods and their effects on field estimates of belowground net primary production. In: Mancuso S (ed) Measuring Roots. Springer, Berlin, pp 303-339. https://doi.org/10.1007/9783-642-22067-8

Monostori I, Árendás T, Hoffman B, Galiba G, Gierczik K, Szira F, Vágújfalvi A (2016) Relationship between SPAD value and grain yield can be affected by cultivar, environment and soil nitrogen content in wheat. Euphytica 211:103-112. https://doi.org/10.1007/ s10681-016-1641-z

Oliveira MRG, van Noordwijk M, Gaze SR, Brouwer G, Bona S, Mosca G, Hairiah K (2000) Auger sampling, ingrowth cores and pinboard methods. In: Smit AL, Bengough AG, Engels C, van Noordwijk M, Pellerin S, van de Geijn SC (eds) Root methods: a handbook. Springer, Berlin, pp 175-210. https://doi. org/10.1007/978-3-662-04188-8

Ouerghi Z, Cornic G, Roudani M, Ayadi A, Brulfert J (2000) Effect of $\mathrm{NaCl}$ on photosynthesis of two wheat species (Triticum durum and T. aestivum) differing in their sensitivity to salt stress. $\mathrm{J}$ Plant Physiol 156:335-340. https://doi.org/10.1016/S0176 $-1617(00) 80071-1$

Postic F, Doussan C (2016) Benchmarking electrical methods for rapid estimation of root biomass. Plant Methods 12:33. https:// doi.org/10.1186/s13007-016-0133-7

Rajkai K, Végh RK, Nacsa T (2005) Electrical capacitance of roots in relation to plant electrodes, measuring frequency and root media. Acta Agron Hung 53:197-210. https://doi.org/10.1556/ AAgr.53.2005.2.8

Repo T, Zhang MIN, Ryyppö A, Rikala R (2000) The electrical impedance spectroscopy of Scots pine (Pinus sylvestris L.) shoots in relation to cold acclimation. J Exp Bot 51:2095-2107. https://doi. org/10.1093/jexbot/51.353.2095
Sairam RK, Rao KV, Srivastava GC (2002) Differential response of wheat genotypes to long term salinity stress in relation to oxidative stress, antioxidant activity and osmolyte concentration. Plant Sci 163:1037-1046. https://doi.org/10.1016/S0168-9452(02)00278-9

Suhayda CG, Giannini JL, Briskin DP, Shannon MC (1990) Electrostatic changes in Lycopersicon esculentum root plasma membrane resulting from salt stress. Plant Physiol 93:471-478. https://doi. org/10.1104/pp.93.2.471

Weigand M, Kemna A (2017) Multi-frequency electrical impedance tomography as a non-invasive tool to characterize and monitor crop root systems. Biogeosciences 14:921-939. https://doi. org/10.5194/bg-14-921-2017

Weigand M, Kemna A (2019) Imaging and functional characterization of crop root systems using spectroscopic electrical impedance measurements. Plant Soil. https://doi.org/10.1007/s1110 4-018-3867-3

Wright D, Rajper I (2000) An assessment of the relative effects of adverse physical and chemical properties of sodic soil on the growth and yield of wheat (Triticum aestivum L.). Plant Soil 223:277-285. https://doi.org/10.1023/A:1004882523013

Yang C, Wang P, Li C, Shi D, Wang D (2008) Comparison of effects of salt and alkali stresses on the growth and photosynthesis of wheat. Photosynthetica 46:107-114. https://doi.org/10.1007/ s11099-008-0018-8

Publisher's Note Springer Nature remains neutral with regard to jurisdictional claims in published maps and institutional affiliations. 